\title{
Changes in the tax accounting policy of industrial enterprises in the context of digitalization
}

\author{
$L$ Pudeyan ${ }^{1, *}, E$ Zaporozceva ${ }^{1}, T$ Medvedskaya ${ }^{1}$, and $O$ Yureva ${ }^{1}$ \\ ${ }^{1}$ Don State Technical University, Gagarin sq., 1, Rostov on Don, 344003, Russia
}

\begin{abstract}
Recently, approaches to organizing tax accounting policies in enterprises have undergone significant changes. The strict regulation of the accounting process by the state has been replaced by a combination of state regulation and the independence of enterprises in setting and maintaining accounting and tax accounting. In this article, the authors investigated the issue of tax accounting policy as a mechanism for managing taxes in the system of financial and economic activity of an enterprise. The method of influence of tax policy on financial indicators of activity of the business entity is shown. The article notes the fact that the development of accounting policy is carried out formally. The potential consequences of applying tax accounting policy elements are not taken into account. It highlights the importance and the need for careful accounting tax policies. It is necessary to take into account the relationship of such financial indicators as gross profit, retained earnings, tax liabilities, profitability, depreciation of fixed assets, liquidity, financial sustainability with the strategic development plans of the organization. In the process of developing the methodological section of the modern accounting policy in the section of keeping records of existing inventory, it is necessary to focus on the choice of the method for their valuation. The authors propose to use the approach in order to determine the tax potential of the business entity of the analyzed sector using an indicator of current actual turnover, taking into account the allocation of categories and groups. The main features of the model on comprehensive taxation of economic entities of the region are displayed, forecasts of all tax revenues for existing groups are formed.
\end{abstract}

\section{Introduction}

Relevance of the study. Recently, approaches to organizing tax accounting policies in enterprises have undergone significant changes. The strict regulation of the accounting process by the state was replaced by a combination of state regulation and the independence of enterprises in setting and maintaining accounting and tax accounting. The essence of the new approaches to the organization of tax accounting policy is manifested mainly in the fact that in order to solve the tasks facing them, organizations are given the right to

* Corresponding author: pudeyan.liuba@yandex.ru 
independently develop tax accounting policy, following the general rules established by the state in the field of accounting.

The relevance of this study is due to the lack of an algorithm to solve a large number of issues, including the assessment of tax potential. The proposed methods are based on the use of different approaches, including indirect and direct estimates of tax revenues, as well as indicators of the current economic activity of the subject, etc. [7-9]

The process of applying techniques that are based on notation and description is called the algorithm for generating tax models $[6,8]$. The purpose of the application is the development of "contactless ways of interaction between payers and tax authorities" [5].

Constructive tools are used to complement and develop their descriptive nature. When solving problems related to stability, the process of stimulating business processes, developing the tax potential of subjects "improving budget and tax legislation and improving the system and mechanism of tax administration" [1] is carried out by complex models.

Practice shows that in many organizations the importance of tax accounting policies is comprehensively underestimated. Its development is carried out formally, without taking into account the possible consequences of the use of its individual elements. Meanwhile, the role of accounting policy in the formation of financial indicators of the organization is obvious: it has a great impact on income and expenses, financial results, taxes, and financial condition.

Thus, the object of the study was the practical and theoretical provisions of the tax accounting policy of the organization.

The subject of this article is the conditions for the implementation of the tax accounting policy for the implementation of the tax management mechanism in the system of financial and economic activity of the enterprise.

The purpose of the article is to develop a model of tax accounting policy in order to manage taxes in the system of financial and economic activity of the enterprise.

The practical significance lies in the possibility of using the results of the study by business entities to implement the proposed model of implementing an accounting tax policy, improving the financial and economic activities of the enterprise.

\section{Materials and methods}

In order to determine the tax potential of industry, it is necessary to use the actual turnover rate for the activities in question to ensure the objectivity of the assessment being made as a result of the use of general economic methods for the analysis of statistical data, the ability to generate their forecast. The present study presents a model for the implementation of a multi-purpose integrated taxation.

It is generally accepted that thanks to the application of the model of implementing a comprehensive tax assessment, it will provide an opportunity to implement the basic principles of comprehensiveness and simplicity of the tax assessment, will form the prerequisites for the growth of the tax potential of some activities, the region.

Simple and understandable mechanisms with a comprehensive approach participate in expanding business growth factors with minimizing the influence of negative factors.

Tax accounting is a system for summarizing information on the definition of a tax base using data from primary documents classified according to the Tax Code of the Russian Federation. [2]

The implementation of tax accounting takes place in order to determine the exact information about accounting for the purposes pursued by the tax levy, according to the economic transactions realized by the entity during the reporting period. Used to control the 
correct, timely, full calculation, payment of tax to the budget, its display to external and internal users [7].

As you know, any commercial enterprise aims at profiting from financial and economic activities. It is clear that the issues of profit optimization while strengthening financial condition are very important. These issues are often addressed by a well-designed accounting policy, which is a set of methodological techniques that allows you to present the financial result and financial condition of an organization from a certain perspective. Profit is expressed as the difference between income and expenditure, and therefore the choice of how to recognize it in accounting can significantly affect the final financial result, increasing or decreasing it. The amount of income is influenced by the fact of its recognition, as well as the choice of the method of recognition: payment (cash method) or shipment (accrual method). The impact of accounting policies on financial performance should be measured by indicators such as gross profit, retained earnings, tax liabilities, profitability, depreciation of fixed assets, liquidity, financial sustainability. At the same time, it is very important to rely not only on the results of the analysis of changes in these indicators, but also take into account their relationship with the strategic development plans of the organization.

In order to increase the efficiency and balance of development, it is necessary to modernize taxation. The process aimed at stabilizing the tax system complies with the requirements for increasing productive capacity, the tasks of implementing the model of long-term economic growth $[2,3]$. For example, mechanisms that are based on assessing tax potential, forming a model for implementing a comprehensive tax assessment of industrial economic entities.

The essence of this model is to use the existing capabilities of the tax regime, combining them. Modelling is necessary for economic development so that in the future it is possible to carry out direct balanced development of industrial companies, as well as to increase the current tax potential.

It should also be pointed out that the process of directly forming the goal is the process of achieving the developed sub-goals for obtaining the required condition, namely: to increase the financial indicators of the economic activities of industrial entities, investment attractiveness, etc.

A multi-purpose character is present in the model of complex taxation. The facility is an industry in the region that modernizes the tax potential, assessing the expected results.

Display the main features of the complex model in Figure 1.
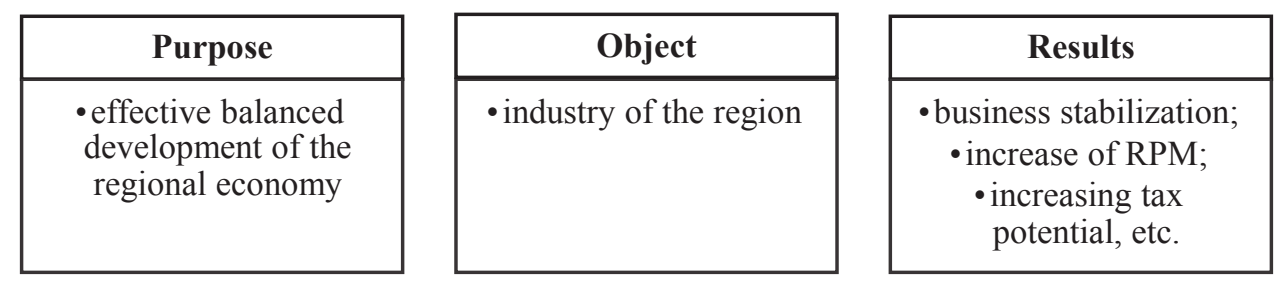

Fig. 1. Characteristics of the model of implementation of integrated taxation.

\section{Results}

Results of application: indicators of activity of economic entities on their contribution to the development of the region's economy, including the tax sphere. These are: indicators that can act as the main object of tax taxation: turnover, profit or income. This can increase tax revenues for tax and economic stability. 
It should be noted that the idea of combining modes appeared quite a long time ago. However, to this day there is a large number of discussions related to the justification or choice of regime for the business entity [9].

Proposals related to the replacement of different tax systems, which are based on different objects as profit or income, have expressed reasons.

In fact, the tax taxation systems that are used in industry: USN (simplified tax taxation system), PSN (patent tax taxation system), the general tax taxation regime, can be replaced by a system of comprehensive tax taxation. As a result, issues related to the transition of the system are eliminated. To date, a large number of restrictions related to their use have been eliminated in legislation.

It turns out that tax accounting is carried out for the accurate calculation of tax obligations, payment on time. While accounting is necessary in order to collect data on the financial and economic activities of the business entity.

This information is in demand for the management of the business entity, as well as for investors [3]. The manager determines the ways of implementing the strategic development of the business entity, based on the basic information to identify the economic sustainability of the business entity.

The main general features of these systems: mandatory, provision in monetary terms, display of business results, timing of submission, reporting.

The main differences of these systems: the method of management due to the different goals pursued.

Options for the existence of these types of accounting, allocated by scientists:

- creation of a subdivision for tax accounting, i.e. parallel maintenance of accounting and tax accounting by different structural units;

- change of profit on the FU in accordance with the purposes of tax taxation.

Tax accounting registers include accounting registers;

- used in computer specialized programs.

Enter your own chart of accounts for tax accounting, which correlates with the existing chart of accounts. In this way, the accountant will be able to display the transactions in the existing tax and accounting accounts with simultaneous recording;

- used by small business instead of accounting. Accounting is maintained in accounting accounts, while expenses and revenues are generated in accordance with tax accounting requirements. On the basis of Art. 12 Ф3-402 On accounting, business entities are obliged to generate financial statements to display a real reliable financial position.

It turns out that, despite the different goals of maintaining tax and accounting, the obligatory condition for their maintenance is literacy.

Managers must make the right decision based on many factors when choosing how these systems interact. But at the same time, they need to determine how to implement the accounting functions of these systems, choose the appropriate model, and change it if necessary.

It turns out that the tax accounting policy of an economic entity is a way of forming the size of financial indicators of activities carried out by an economic entity, the price of policy and tax planning.

In the absence of the required information on the maintenance of accounting policy, there are difficulties in identifying the dynamics of the development of the business entity, in conducting a comparative analysis of its indicators with the indicators of the main competitors, as well as in identifying its role and place in the market. Due to a well-formed accounting policy, it is possible to ensure effective interaction between participants in the accounting process, as well as reduce to the maximum the costs (labor, temporary, material) associated with resolving various kinds of difficulties that arise. 


\section{Conclusion}

The application of the model for the implementation of a comprehensive tax taxation will allow to implement the basic principles of simplicity, accessibility of tax taxation, will form new prerequisites for increasing the tax potential of some types of economic activities of the economic entity and the region:

- the presence of a loyal system of tax rates acts as an incentive factor for increasing the turnover of types of industry, where there is no stable tax potential in accordance with preliminary estimates;

- Due to the stabilization of tax conditions, the development of economic entities of various crops can be balanced mainly with positive dynamics;

- application of the model for implementation of the comprehensive tax assessment will provide an opportunity to increase their competitive ability, implement the forecast for potential growth of existing tax revenues;

- The proposed model has the properties of a compensatory mechanism to ensure the leveling of many factors of negative impact on the development of business in the region.

The problem of exploring the feasibility of implementing tax processes cannot be fully solved by the results of this study. For its further study, it is necessary to solve the problems of identifying the possibility of adding to the model for the implementation of a comprehensive tax assessment of various additional areas of activity in the form of an object, applying profit indicators in order to assess the tax potential of business entities, their associations, and increasing the number of forecasts, taking into account the integration or differentiation of rates.

\section{References}

1. V.Y. Plaksiienko, M.V. Yermolaieva, K.V. Chernenko, R.V. Lipskyi, T.O. Melikhova, Academy of Accounting and Financial Studies Journal 23(2) (2019)

2. J. Lole, Accounting principles for tax purposes (Haywards Heath, Bloomsbury Professional, 2017)

3. Corporate taxation for the future: competitive, simple and predictable: in tax systems, less is often more! (Publications Office of the European Union, Luxembourg, 2019)

4. A. Grinko, I. Voloshenyuk, Eureka: Social and Humanities 5(5), 3-10 (2016)

5. L. Liu, R. Altshuler, Nat. Tax J. 66(1), 215-238 (2013)

6. J. Creedy, N. Hérault, Fiscal Studies 36(2), 157-180 (2015)

7. H.E. Carter, D.J. Schofield, R. Shrestha, L. Veerman, PLoS ONE 14(7), e0220209 (2019)

8. N. Ostapiuk, J. Stashenko, Technology audit and production reserves 4(46), 11-15 (2019)

9. C. Lennox, P. Lisowsky, J. Pittman, Tax Aggressiveness and Accounting Fraud Journal of Accounting Research 51(4), 739-778 (2013)

10. J. Downing, C.J. Langli, Accounting and Business Research Audit Exemptions and Compliance with Tax and Accounting Regulations 49(1), 28-67 (2018)

11. R. Clemons, T.J. Shevlin, Journal of American Taxation Association 38(1), 29-37 (2016) 
12. M.Zh. Daribayeva, Y. Zhang, Topical issues of contemporary science. Collection of scientific articles, 117-119 (2017)

13. M. Mauboussin, More than you know Finding Financial Wisdom in Unconventional Places (Alpina Publisher, Moscow, 2018)

14. S. Ryza, U. Leserson, S. Owen, J. Wills, Spark for professionals Modern patterns of big data processing (Piter, St. Petersburg, 2017)

15. M.V. Gestrin, J. Staudt, The digital economy, multinational enterprises and international investment policy (2018) http://www.oecd.org/investment/investmentpolicy/The-digital-economy-multinationalenterprises-and-international-investmentpolicy.pdf

16. L. Pushkareva, M. Pushkarev, E3S Web of Conferences 164, 10027 (2020) doi:10.1051/e3sconf/202016410027

17. E.M. Akhmetshin et al, European Research Studies Journal 21(3), 130-141 (2018) 